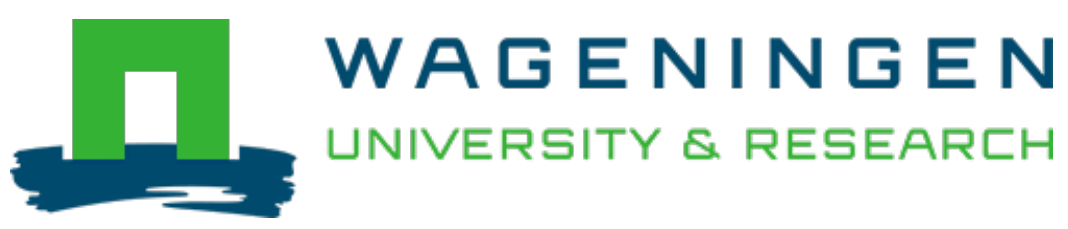

\title{
Regional gene flow and population structure of the wind-dispersed plant species Hypochaeris radicata (Asteraceae) in an agricultural landscape
}

\author{
Molecular Ecology \\ Mix, C.; Arens, P.F.P.; Rengelink, R.; Smulders, M.J.M.; Groenendael, J.M. et al \\ https://doi.org/10.1111/j.1365-294X.2006.02887.X
}

This article is made publicly available in the institutional repository of Wageningen University and Research, under the terms of article $25 \mathrm{fa}$ of the Dutch Copyright Act, also known as the Amendment Taverne. This has been done with explicit consent by the author.

Article 25 fa states that the author of a short scientific work funded either wholly or partially by Dutch public funds is entitled to make that work publicly available for no consideration following a reasonable period of time after the work was first published, provided that clear reference is made to the source of the first publication of the work.

This publication is distributed under The Association of Universities in the Netherlands (VSNU) 'Article $25 \mathrm{fa}$ implementation' project. In this project research outputs of researchers employed by Dutch Universities that comply with the legal requirements of Article $25 \mathrm{fa}$ of the Dutch Copyright Act are distributed online and free of cost or other barriers in institutional repositories. Research outputs are distributed six months after their first online publication in the original published version and with proper attribution to the source of the original publication.

You are permitted to download and use the publication for personal purposes. All rights remain with the author(s) and / or copyright owner(s) of this work. Any use of the publication or parts of it other than authorised under article $25 \mathrm{fa}$ of the Dutch Copyright act is prohibited. Wageningen University \& Research and the author(s) of this publication shall not be held responsible or liable for any damages resulting from your (re)use of this publication.

For questions regarding the public availability of this article please contact openscience.library@wur.nl 


\title{
Regional gene flow and population structure of the wind-dispersed plant species Hypochaeris radicata (Asteraceae) in an agricultural landscape
}

\author{
C. MIX, ${ }^{*}$ P. F. P. ARENS, † R. RENGELINK, ${ }^{*}$ M. J. M. SMULDERS,† J. M. VAN GROENENDAEL* \\ and N. J. OUBORG* \\ *Department of Ecology, Radboud University Nijmegen, Toernooiveld 1, 6525 ED Nijmegen, The Netherlands, +Plant Research \\ International, Wageningen UR, PO Box 16,6700 AA Wageningen, The Netherlands
}

\begin{abstract}
Using microsatellites, we investigated population structure and gene flow of the short-lived, wind-dispersed plant species Hypochaeris radicata in a fragmented agricultural landscape where more than $99 \%$ of the nutrient-poor grasslands have disappeared over the last century. We sampled populations in the few remaining high density populations in conservation areas, as well as individuals that occurred, with lower densities, in linear landscape elements, at two spatial scales. In a re-inventory of the landscape, after 3 years, both extinctions and colonizations of populations were observed. Contrary to expectations, no differences in genetic diversity between high and low density populations were observed. Both types of populations had relatively high levels of diversity. Overall genetic differentiation $(\theta)$ was 0.04 and significantly different from zero $(P<0.01)$. A significant isolation-by-distance pattern was found when all populations were simultaneously analysed $(r=0.24, P=0.013)$. Isolation by distance was (marginally) significant at the small scale $(r=0.32, P=0.06)$, whereas nonsignificant at the large spatial scale $(r=-0.05, P=0.66)$. A maximization-of-explained-variance procedure resulted in a threshold distance of $3.5 \mathrm{~km}$ above which populations were effectively genetically isolated. An additional partial exclusion Bayesian-based assignment test showed that overall $32.3 \%$ of the individuals were assigned to their population of origin, $48 \%$ were assigned to another population in the area and $19.7 \%$ were not assigned. Together, these results suggest high levels of gene flow. Seed dispersal contributes to the observed gene flow up to several hundred metres, which is higher than previously modelled using aerodynamic models on seed dispersal of $H$. radicata. We discuss the consequences of these results for an evaluation of the probability of persistence of this species in the fragmented landscape.

Keywords: agricultural landscape, Bayesian assignment, dispersal, gene flow, Hypochaeris radicata, metapopulation, microsatellites

Received 20 May 2005; revision received 8 September 2005; accepted 23 September 2005
\end{abstract}

\section{Introduction}

Habitat fragmentation is generally recognized as a major threat to plant population persistence. A progressive reduction of suitable habitats has led to smaller populations separated by often unbridgeable unsuitable habitats. As a result, populations face the consequences of demographic,

Correspondence: Carolin Mix, Fax: +31 24 3652134; E-mail: c.mix@science.ru.nl environmental and genetic stochasticity (Schaffer 1987), increasing the probability of extinction (Lande 1993; Schemske et al. 1994). Genetic stochasticity, for instance, can negatively affect population persistence. Random changes in allele frequencies can lead to a loss of alleles or to the fixation of deleterious mutations, resulting in reduced genetic diversity (Hartl \& Clark 1989) and lower fitness of the offspring (Byers \& Waller 1999). The result is genetic divergence between populations and an alteration of regional population structure and metapopulation dynamics (Hutchison \& Templeton 1999). 
Gene flow can counterbalance the reduction in genetic diversity of individual populations by bringing in new genetic material through seeds and pollen (Young et al. 1996). Dispersal of genetic material through seeds enables the founding of new populations, while dispersal through pollen can bridge existing populations, often over greater distances. In a fragmented landscape, the success of these two processes depends on a number of factors. For example gene flow can be limited as a result of lower plant densities after habitat fragmentation (Griffin \& Barrett 2004). Seed dispersal, moreover, depends very much on a species' dispersal characteristics. For example, wind-dispersed plumed seeds have a lower terminal velocity and travel greater distances than plumeless seeds (Soons \& Heil 2002; Tackenberg 2003). Pollen dispersal greatly depends on pollen dispersal vectors. For example, plant-pollinator interactions for insect-pollinated species are often disrupted in fragmented habitats, leading to reduced pollen transfer by pollinators (Kwak et al. 1998; Lennartsson 2002). The effectiveness of pollinators may also be affected by plant densities as indicated by a lower number of pollinators in populations with a lower density (Karron et al. 1995; Kunin 1997), which may result in lower outcrossing rates (Van Treuren et al. 1994). Pollinators are especially important for gene flow in species that are self-incompatible (Goodell et al. 1997).

Thus, while successful gene flow could rescue populations from genetic erosion (Brown \& Kodric-Brown 1977), isolation between habitat patches aggravates the problem, not only because it reduces gene flow but also because it changes dispersal ability in an evolutionary sense through selection against dispersal in patches isolated in a hostile environment (Cody \& Overton 1996). Given the importance of gene flow for the future persistence of plant species, there is a particular need for studies to provide measures of dispersal (i.e. gene flow) at various spatial scales.

Since direct estimates of realistic dispersal rates are difficult to obtain, it has been more common to apply indirect methods such as the use of molecular markers to estimate gene flow (Ouborg et al. 1999). Traditionally, $F_{\mathrm{ST}}$ values (or related measures of population differentiation) have been widely used to infer the number of migrants $(\mathrm{Nm})$ and so determine dispersal. The reliability of such population differentiation measures, however, has been questioned (Whitlock \& McCauley 1999), because these measures rely on unrealistic assumptions (Cain et al. 2000 and references therein). More recent studies have demonstrated that assignment tests or assignment-based differentiation measures are more appropriate in determining particularly contemporary levels of gene flow (Tero et al. 2003; Berry et al. 2004; He et al. 2004; Manel et al. 2005).

In the present study, we used highly polymorphic microsatellite loci and assignment procedures to investigate gene flow and population structure of Hypochaeris radicata (Asteraceae) at two different spatial scales within a highly fragmented agricultural landscape. Within the study area, and equally distributed over both spatial scales, two types of populations are present: high density populations occurring in conservation areas under strict management, and low density populations occurring in nonprotected road verges. The investigated landscape therefore provides an ideal situation to study population structure in relation to spatial scale and to compare levels of genetic diversity between high density and low density populations after habitat fragmentation.

Hypochaeris radicata is a short-lived, mainly outcrossing and insect-pollinated herb that does not form a seed bank (Fryxell 1957; Aarssen 1981). The species produces singleseeded fruits equipped with a plumose pappus that is attached to a beak, allowing dispersal by wind (Soons et al. 2004). Seed dispersal distance calculations based on aerodynamic properties of the seeds have shown that most of them would not disperse more than $100 \mathrm{~m}$, whereas a small fraction may bridge distances up to $400 \mathrm{~m}$ (Soons et al. 2004). Previous studies have shown that $H$. radicata is sensitive to inbreeding on seed and dispersal traits (Picó et al. 2004; Mix et al. 2006) and that the species' colonization capacity is reduced in fragmented landscapes (Cody \& Overton 1996; Soons \& Heil 2002). These characteristics indicate that the species may be sensitive to habitat fragmentation. This can have two effects: low density populations may show reduced genetic diversity, and increased interpopulation distances may reduce the level of gene flow. Thus, we expect the low density populations to have higher inbreeding levels and increased genetic differentiation with other populations. We also expect that population differentiation may be more evident at the larger spatial scale.

\section{Materials and methods}

\section{Study site}

The Achterhoek is a region of about 40 by $30 \mathrm{~km}^{2}$, located in the mid-eastern part of the Netherlands. About a century ago, the vegetation consisted predominantly of nutrient-poor and moist, sandy, species-rich grassland (Nardo-Galion community). Intensive farming has reduced the former nutrient-poor vegetation by as much as $99.9 \%$ (Soons et al. 2004), and species-rich sites nowadays occur as small, isolated fragments, managed as conservation areas. Hypochaeri radicata L. still occurs in this region as an abundant species present in conservation areas in high densities ( $>5$ individuals $/ \mathrm{m}^{2}$ ), as well as in linear elements like roadside ditches, the banks of waterways and railway tracks where the species has a low density $(<0.02$ individuals $/ \mathrm{m}^{2}$ ). 


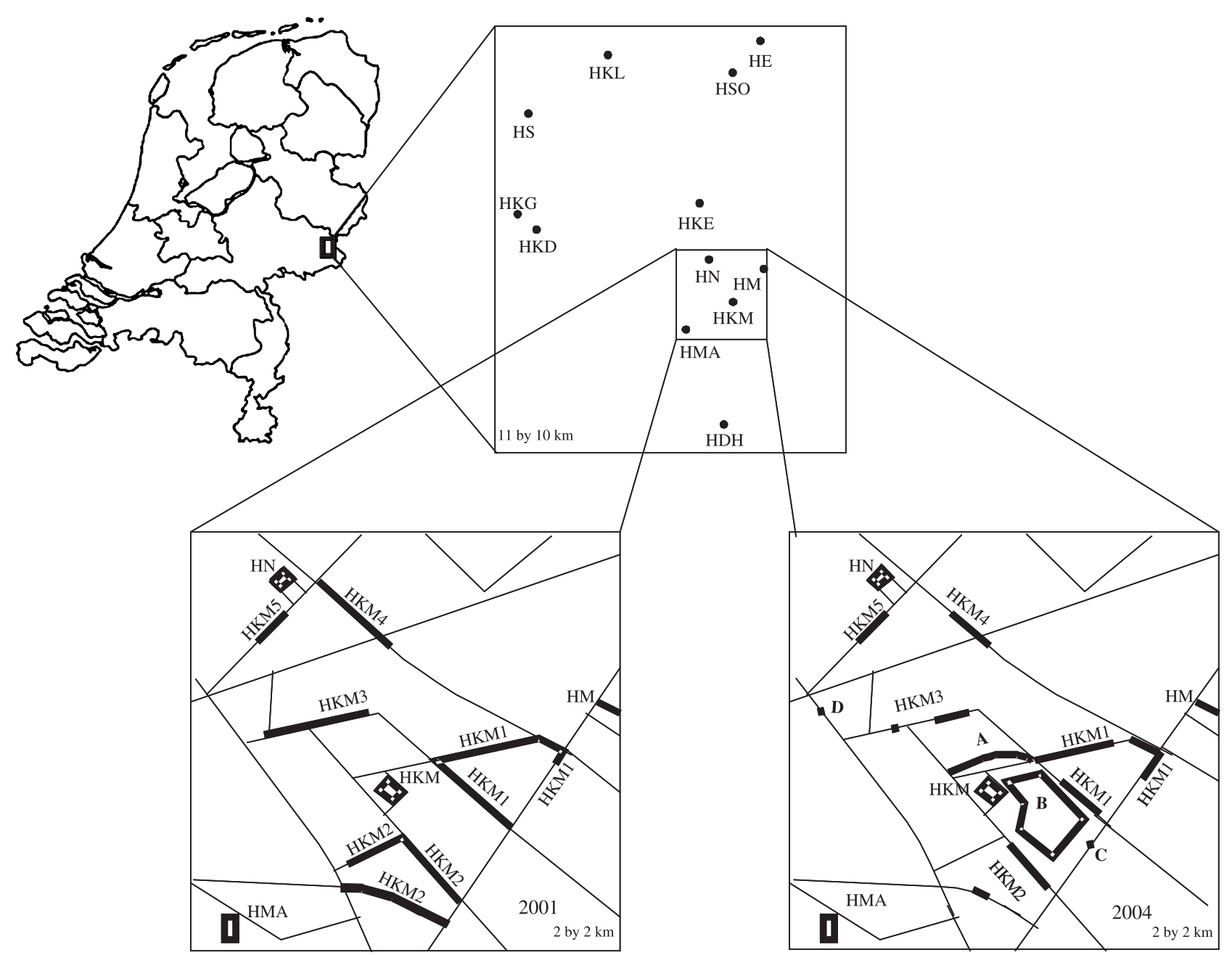

Fig. 1 Map of the Achterhoek region, showing the Hypochaeris radicata populations of the large- and small-scale sampling schemes in 2001. The dynamics of these populations has been visualized by also showing the distribution of populations in the small-scale sampling area in 2004.

\section{Sampling strategy}

In 2001, we sampled populations at two different scales (Fig. 1). First, we sampled all populations $(n=9)$ in an area of 2 by $2 \mathrm{~km}$ (small scale), chosen based on the maximum dispersal distance reported for $H$. radicata (Soons et al. 2004). Second, we additionally sampled a random selection of eight populations within an area of approximately 11 by $10 \mathrm{~km}$ (large scale). We defined a population as a group of individuals of $H$. radicata separated from the neighbouring group by a distance of at least $400 \mathrm{~m}$. All populations have small population sizes (below 150), except for the population HKM (50 000) and HKD (600). Variation between population sizes was insufficient for further analysis.

The geographical distances between the populations in the small-scale study varied from 0.5 to $3.35 \mathrm{~km}$. All individuals in the HKM1, HKM3 and HKM5 populations were sampled. Since the HKM2 and HKM4 populations had relatively high plant densities, we sampled 33 and 37 individuals in these populations every $2 \mathrm{~m}$ along a linear transect. In order to determine the spatial dynamics [cf. extinction and (re)colonization] of populations, we revisited the small-scale sampling area in 2004 and screened all possible sites and linear elements again for the presence or absence of $H$. radicata (Fig. 1).

Within the large-scale study, the distances between sampled populations varied from $0.45 \mathrm{~km}$ to $11.0 \mathrm{~km}$; note that four populations are part of both the small-scale and the large-scale analysis (Table 1). Here we sampled between 12 and 30 individuals in each population, again by taking a sample every $2 \mathrm{~m}$ along a linear transect, except for populations $\mathrm{HE}, \mathrm{HKE}, \mathrm{HN}$, and HMA where all individuals were sampled.

At both scales of study both high density ( $n=3$ for small scale and $n=4$ for large scale) and low density populations were sampled and analysed (Table 1). 
Table 1 Characterization of the Hypochaeris radicata populations in the Achterhoek region sampled in the large-scale scheme (LS: 12 populations over an area of $110 \mathrm{~km}^{2}$ ) and the small-scale scheme (SS: nine populations within $4 \mathrm{~km}^{2}$ )

\begin{tabular}{|c|c|c|c|c|c|c|c|}
\hline \multirow[b]{2}{*}{ Population name } & \multirow[b]{2}{*}{ Code } & \multirow[b]{2}{*}{ Geographical coordinates } & \multirow[b]{2}{*}{ Plant density } & \multirow{2}{*}{$\begin{array}{l}\text { No. of plants } \\
\text { sampled }\end{array}$} & \multicolumn{3}{|c|}{ Sampling strategy } \\
\hline & & & & & LS & or & SS \\
\hline De Hare & $\mathrm{HDH}$ & $51^{\circ} 59^{\prime} 22^{\prime \prime} \mathrm{N}, 6^{\circ} 32^{\prime} 41^{\prime \prime} \mathrm{E}$ & Low density & 30 & LS & & \\
\hline Konijnendijk greppel & HKG & $52^{\circ} 02^{\prime} 38^{\prime \prime} \mathrm{N}, 6^{\circ} 26^{\prime} 09^{\prime \prime} \mathrm{E}$ & Low density & 30 & LS & & \\
\hline Eibergseweg & $\mathrm{HE}$ & $52^{\circ} 04^{\prime} 49^{\prime \prime} \mathrm{N}, 6^{\circ} 34^{\prime} 49^{\prime \prime} \mathrm{E}$ & Low density & 20 & LS & & \\
\hline Kempersweg & HKE & $52^{\circ} 02^{\prime} 31^{\prime \prime} \mathrm{N}, 6^{\circ} 32^{\prime} 18^{\prime \prime} \mathrm{E}$ & Low density & 17 & LS & & \\
\hline Kooierlaan & HKL & $52^{\circ} 05^{\prime} 05^{\prime \prime} \mathrm{N}, 6^{\circ} 31^{\prime} 80^{\prime \prime} \mathrm{E}$ & Low density & 21 & LS & & \\
\hline Het Spoor & HS & $52^{\circ} 04^{\prime} 06^{\prime \prime} \mathrm{N}, 6^{\circ} 28^{\prime} 43^{\prime \prime} \mathrm{E}$ & Low density & 28 & LS & & \\
\hline Konijnendijk & HKD & $52^{\circ} 02^{\prime} 06^{\prime \prime} \mathrm{N}, 6^{\circ} 26^{\prime} 53^{\prime \prime} \mathrm{E}$ & High density & 30 & LS & & \\
\hline Sonderenweg & $\mathrm{HSO}$ & $52^{\circ} 04^{\prime} 30^{\prime \prime} \mathrm{N}, 6^{\circ} 34^{\prime} 00^{\prime \prime} \mathrm{E}$ & Low density & 30 & LS & & \\
\hline Molenweg & $\mathrm{HM}$ & $52^{\circ} 01^{\prime} 43^{\prime \prime} \mathrm{N}, 6^{\circ} 34^{\prime} 53^{\prime \prime} \mathrm{E}$ & Low density & 30 & LS & & SS \\
\hline Nijkampseheide & $\mathrm{HN}$ & $52^{\circ} 01^{\prime} 51^{\prime \prime} \mathrm{N}, 6^{\circ} 32^{\prime} 41^{\prime \prime} \mathrm{E}$ & High density & 23 & LS & & SS \\
\hline Maatweg & HMA & $52^{\circ} 00^{\prime} 45^{\prime \prime} \mathrm{N}, 6^{\circ} 32^{\prime} 25^{\prime \prime} \mathrm{E}$ & High density & 12 & LS & & SS \\
\hline Koolmansdijk & HKM & $52^{\circ} 01^{\prime} 13^{\prime \prime} \mathrm{N}, 6^{\circ} 33^{\prime} 13^{\prime \prime} \mathrm{E}$ & High density & 30 & LS & & SS \\
\hline Around HKM 01-31 & HKM1 & $52^{\circ} 01^{\prime} 16^{\prime \prime} \mathrm{N}, 6^{\circ} 33^{\prime} 44^{\prime \prime} \mathrm{E}$ & Low density & 31 & & & SS \\
\hline Around HKM 32-64 & HKM2 & $52^{\circ} 01^{\prime} 01^{\prime \prime} \mathrm{N}, 6^{\circ} 33^{\prime} 14^{\prime \prime} \mathrm{E}$ & Low density & 33 & & & SS \\
\hline Around HKM 65-76 & HKM3 & $52^{\circ} 01^{\prime} 27^{\prime \prime} \mathrm{N}, 6^{\circ} 32^{\prime} 53^{\prime \prime} \mathrm{E}$ & Low density & 12 & & & SS \\
\hline Around HKM 77-113 & HKM4 & $52^{\circ} 01^{\prime} 43^{\prime \prime} \mathrm{N}, 6^{\circ} 33^{\prime} 03^{\prime \prime} \mathrm{E}$ & Low density & 37 & & & SS \\
\hline Around HKM 114-124 & HKM5 & $52^{\circ} 01^{\prime} 39^{\prime \prime} \mathrm{N}, 6^{\circ} 32^{\prime} 34^{\prime \prime} \mathrm{E}$ & Low density & 11 & & & SS \\
\hline
\end{tabular}

\section{DNA isolation and microsatellite application}

In May 2002, leaf material of 11 up to 37 individuals from the 17 populations (Table 1) was collected and kept at $-80^{\circ} \mathrm{C}$ until further analysis. DNA was isolated using DNeasy Plant Mini Kit (QIAGEN). The plants were genotyped using five microsatellite loci (HrGA9, 10, 12, 14 and HrGT4; Mix et al. 2004). Analysis of the complete data set showed significant linkage between HrGA9 and HrGA12, as was also found previously in another data set (Mix et al. 2004). Preliminary analyses showed that excluding either HrGA9 or HrGA12 led to the same results, therefore we decided to exclude HrGA12 for which a few missing values were present in the data set. Amplifications were performed on a T3 Thermocycler (Biometra) following the protocols developed by Mix et al. (2004). Fragments were analysed on the LI-COR 4200 IR$^{2}$ DNA analyser (LI-COR). Bands were scored using the SAGAGT software (LI-COR).

\section{Effects of density on within-population diversity}

The following measures of within-population genetic diversity were calculated for low density and high density populations: allele number $A$, allelic richness $R_{\mathrm{t}}$, gene diversity $\left(H_{\mathrm{E}}\right)$ (according to Nei 1973), observed heterozygosity $\left(H_{\mathrm{O}}\right)$ and inbreeding coefficient $F_{\text {IS }}$ per population and per locus using FSTAT version 2.9.3 (Goudet 1995, 2001). Allelic richness value $R_{\mathrm{t}}$ in the small-scale study was corrected for differences in sample size between populations by applying the rarefaction procedure described by Kalinowski (2004) using the program HP-RARE (Kalinowski 2005). Heterozygote excess and deficit were computed per locus, per population and across all populations using GENEPOP 3.4 (Raymond \& Rousset 1995). The program was also used to test for multilocus-based departures from Hardy-Weinberg, using 400 batches and 1000 iterations per batch. A sequential Bonferroni correction was applied (Rice 1989).

We tested for differences of genetic diversity measures between low and high density populations, using one-way ANOVAs. The mean values were normally distributed thus meeting ANOVA assumptions.

\section{Effects of scale on between-population diversity}

Separate statistical analyses were performed for the largescale and small-scale studies. Note that four populations belong to both sets (Table 1) and therefore we did not test for differences between scale levels.

Using FSTAT, overall population differentiation ( $\theta$ ) per locus and per population were calculated according to Weir \& Cockerham (1984). FSTAT provided the standard deviation of $\theta$ by jackknifing across loci (300 replicas were generated). A $t$-test was used to test for significant deviation of $\theta$ from zero.

Assignment tests are considered to be accurate tools to measure contemporary gene flow, being robust to assumptions about the mutation model underlying the molecular markers (Berry et al. 2004; Manel et al. 2005). Gene flow between pairs of populations was estimated using a partial exclusion Bayesian-based assignment test (Rannala \& 
Mountain 1997) implemented in the GENECLAss 2.0 software package (Baudouin et al. 2004). The default settings were applied and the simulations were based on 1000 simulated individuals. GENECLASS 2.0 produces the probability for each individual to belong to the reference population. The number of individuals assigned correctly was determined as the number of individuals with the highest probability assigned to the source population. Additionally, we determined the number of individuals assigned to neighbouring populations as well as those assigned to the rest of the source populations. One of the advantages of the partial exclusion Bayesian-based assignment test is that the true population of origin does not necessarily have to be part of the sampled populations (Manel et al. 2002), as is often the case for highly mobile species (Cegelski et al. 2003). This is likely to be relevant for $H$. radicata in the present study, as we did not sample all populations in the large-scale study. At the small scale, where all populations were sampled, we counted the number of individuals that were not assignable to any of the populations as a measure of dispersal from outside the small-scale area.

To correlate genetic distances with geographical distances, we first used the SPASsIGN program (Pálsson 2004) to calculate estimates of pairwise $F_{\mathrm{ST}}$, termed 'pairwise population genetic distance $\left(D_{\mathrm{LR}}\right)^{\prime}$, based on the partial exclusion Bayesian method by Rannala \& Mountain (1997). The program provided the exact test for pairwise population differentiation based on permutation tests. SPASSIGN includes a Mantel test for the association between $D_{\mathrm{LR}}$ and geographical distances. However, because this program uses geographical latitude and longitude coordinates only as degrees and minutes, it does not allow geographical distances to be analysed with the precision needed for the region we studied. Therefore, we used the Mantel test (Manly 1985) implemented in FSTAT to assess the correlation (in terms of Pearson correlation coefficient) between the $D_{\mathrm{LR}}$-matrix as computed in SPASSIGN and the geographical distance per population pair matrix, as well as to test linear associations between the genetic and geographical distances between populations at both scales (10 000 permutations).

In a simultaneous analysis of both spatial scales we tested for variation in isolation-by-distance patterns between the two scale levels, by moving the threshold geographical distance that separates small-scale and large-scale categories, in such a way as to maximize the percentage explained variance $\left(R^{2}\right)$ in the small-scale pattern.

\section{Results}

\section{Population dynamics}

The small-scale study area was sampled in 2001 and surveyed again in 2004. In 1999, the area adjoining HKM was acquired by the Dutch National Forest Service (site A, Fig. 1). As part of a restoration project, this area was turf-cut in 2001, while in 2002 a cycle path and a ditch were constructed next to the HKM site (site B, Fig. 1), offering potential new habitat for Hypochaeris radicata in this small-scale area.

Except for HKM5, all populations sampled in 2001 had decreased in area, with decreases ranging from about $30 \%$ (HKM1) to 80\% (HKM2). For HKM2, all individuals along one of the roads had disappeared and the number of plants along the ditch was reduced (Fig. 1). In 2004, we found four sites where $H$. radicata had newly established. At the restored sites close to HKM (A and $\mathrm{B}$ ), the species had established the largest number of individuals (several hundreds). At two new sites (C and D), a few $H$. radicata plants had established in linear elements (Fig. 1).

\section{Marker diversity}

Large numbers of alleles $(A)$ were detected for all microsatellite loci, varying from 18 at locus HrGA9 to 43 at locus HrGA10 (Table 2). Allelic richness after rarefaction

Table 2 Descriptive statistics for all loci (a) and all populations (b): measure of differentiation $(\theta)$, allele number $(A)$, allelic richness after rarefaction $\left(R_{\mathrm{t}}\right)$, expected $\left(H_{\mathrm{E}}\right)$ and observed $\left(H_{\mathrm{O}}\right)$ heterozygosity and inbreeding coefficient $\left(F_{\mathrm{IS}}\right)$ per population, calculated following Nei (1973). An asterisk $\left({ }^{*}\right)$ indicates significant values at $P<0.05$ after Bonferroni correction

\begin{tabular}{lrrrrrc}
\hline & \multirow{2}{*}{$\theta$} & \multicolumn{1}{c}{$A$} & $R_{\mathrm{t}}$ & $H_{\mathrm{E}}$ & $H_{\mathrm{O}}$ & \multicolumn{1}{c}{$F_{\mathrm{IS}}$} \\
\hline (a) Per locus & & & & & & \\
HrGT4 & 0.027 & 28 & 3.34 & 0.88 & 0.80 & $0.089^{*}$ \\
HrGA14 & 0.037 & 31 & 3.30 & 0.86 & 0.78 & $0.141^{*}$ \\
HrGA10 & 0.070 & 43 & 3.42 & 0.88 & 0.82 & $0.045^{*}$ \\
HrGA9 & 0.037 & 18 & 3.38 & 0.89 & 0.87 & $0.002^{*}$ \\
(b) Per population & & & & & \\
HDH & & 15.8 & 3.55 & 0.92 & 0.81 & $0.12^{*}$ \\
HKG & & 13.8 & 3.44 & 0.90 & 0.91 & -0.01 \\
HE & & 10.0 & 3.36 & 0.89 & 0.80 & $0.10^{*}$ \\
HKE & & 7.5 & 3.05 & 0.81 & 0.84 & $-0.03^{*}$ \\
HKL & & 11.8 & 3.30 & 0.87 & 0.81 & 0.07 \\
HS & & 13.3 & 3.42 & 0.90 & 0.86 & $0.04^{*}$ \\
HKD & & 14.3 & 3.47 & 0.90 & 0.86 & $0.05^{*}$ \\
HSO & & 11.0 & 3.31 & 0.87 & 0.84 & 0.04 \\
HM & & 13.0 & 3.38 & 0.89 & 0.87 & 0.01 \\
HN & & 12.0 & 3.21 & 0.84 & 0.73 & $0.12^{*}$ \\
HMA & & 7.5 & 3.00 & 0.80 & 0.70 & 0.12 \\
HKM & & 15.3 & 3.46 & 0.91 & 0.78 & 0.14 \\
HKM1 & & 15.3 & 3.44 & 0.91 & 0.83 & $0.09^{*}$ \\
HKM2 & 12.8 & 3.48 & 0.89 & 0.86 & 0.04 \\
HKM3 & 10.8 & 3.42 & 0.90 & 0.79 & 0.12 \\
HKM4 & & 13.8 & 3.39 & 0.89 & 0.83 & 0.07 \\
HKM5 & & 6.3 & 3.40 & 0.92 & 0.84 & 0.09 \\
Overall & 0.040 & 12.0 & 3.36 & 0.88 & 0.82 & 0.04 \\
\hline
\end{tabular}




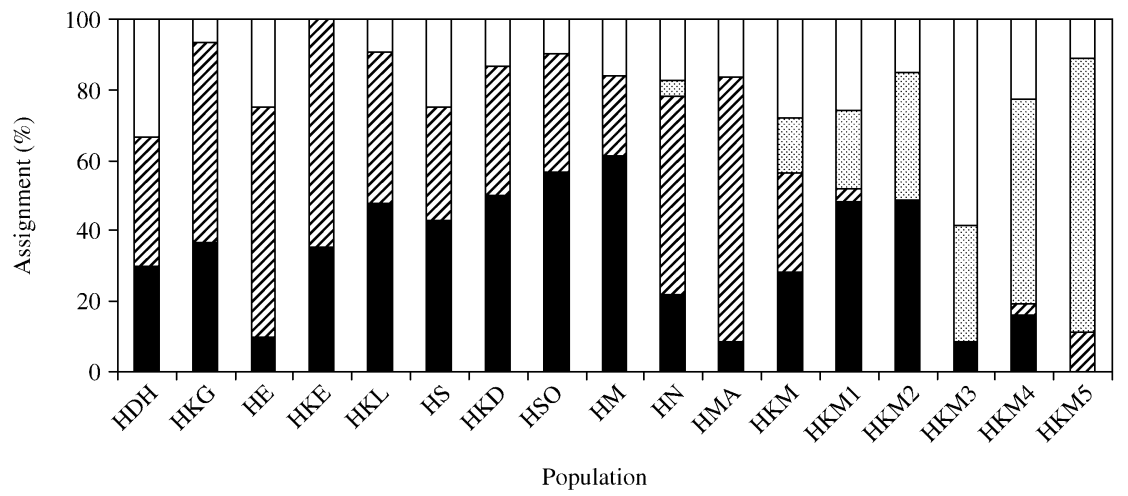

Fig. 2 Results of the assignment test for Hypochaeris radicata. Bar diagram indicates the percentages of individuals per population correctly assigned to the source population (black bars), assigned to neighbouring populations (hatched bar), assigned to other sampled populations (dotted bar) and not assignable to any of the sampled populations (white bar). Since neighbouring populations were not sampled in the large-scale study, this category was excluded.

$\left(R_{\mathrm{t}}\right)$, computed across all loci, ranged from 3.30 (HrGA14) to 3.42 (HrGA10). Expected and observed heterozygosity $\left(H_{\mathrm{E}}\right.$ and $\left.H_{\mathrm{O}}\right)$ ranged from $0.86(0.78)$ at locus HrGA14 to 0.89 (0.87) at locus HrGA19 (Table 2). $\theta$ values per locus ranged from 0.027 (HrGT4) to 0.07 (HrGA10). The inbreeding coefficient $\left(F_{\mathrm{IS}}\right)$ varied between 0.002 at locus HrGA9 and 0.141 at locus HrGA14 (Table 2).

\section{Effects of density on within-population diversity}

The differences between high density and low density populations were nonsignificant for all measures of genetic diversity with the exception of the observed heterozygosity. The mean number of alleles $(A) \pm$ standard error was $12.0 \pm 0.69$ per population (Table 2), $12.28 \pm 1.74$ in high density and $11.94 \pm 0.78$ in low density populations $\left(F_{1,15}=0.04, P=0.84\right)$. Allelic richness after rarefaction $\left(R_{\mathrm{t}}\right)$ computed across all populations was on average $3.36 \pm 0.04,3.29 \pm 0.11$ in high density and $3.38 \pm 0.03$ in low density populations $\left(F_{1,15}=1.31, P=0.27\right)$. Withinpopulation gene diversity $\left(H_{\mathrm{E}}\right)$ was on average $0.88 \pm 0.01$, $0.86 \pm 0.03$ and $0.89 \pm 0.01$ in all, high density and low density populations, respectively $\left(F_{1,15}=1.84, P=0.19\right)$. The inbreeding coefficient $F_{\text {IS }}$ within populations across all loci was on average $0.07 \pm 0.01$, and varied from $0.11 \pm 0.01$ in high density populations to $0.06 \pm 0.01$ in low density populations $\left(F_{1,15}=0.35, P=0.08\right)$. Seven populations showed significant $F_{\mathrm{IS}}$ values $(P<0.001$, Table 2$)$, indicating significant departures from Hardy-Weinberg equilibrium. One population (HKE) showed heterozygote excess, whereas the other six showed some heterozygote deficiency (Table 2).

Average observed heterozygosity $\left(H_{\mathrm{O}}\right)$ was $0.82 \pm 0.01$ (Table 2) and was the only measure that differed significantly between high and low density populations $(0.77 \pm$ 0.04 and $0.84 \pm 0.01$, respectively; $F_{1,15}=8.28, P=0.01$ ). Contrary to our expectations therefore, low density populations had higher observed heterozygosity than high density populations.

\section{Effects of scale on between-population diversity}

The measure of population differentiation across all loci was $0.04(\mathrm{SD}=0.003)$ for both the small-scale and the large-scale study and deviated significantly from zero $(t=231.21, P<0.01)$, indicating that population differentiation was small but significant at both scales of study.

The Bayesian-based assignment test assigned an average of $32.3 \%$ of all individuals $(26.9 \%$ in the small scale and $36.4 \%$ in the large scale) to their own source population (varying between $0.0 \%$ for HKM5 and 61.3\% for HM). In all these cases the next most likely population of assignment was several orders of magnitude less likely, underlining the robustness of this percentage. An average of $19.7 \%$ of the individuals could not be assigned to any of the sampled populations $(16.8 \%$ and $21.1 \%$ for large and small scale, respectively; Fig. 2). The assignment values of correctly assigned and not assignable did not differ significantly between the two scales $\left(F_{1,15}=0.41\right.$ and $0.52 ; P=0.53$ and 0.48 , respectively).

In the small-scale study, a $27.6 \%$ proportion was assigned to their nearest neighbour population (Fig. 2). Since the true neighbouring populations were not known for the large-scale study, we could not determine this percentage for that scale. The remaining individuals were assigned to one of the sampled (but not the neighbouring) populations, indicating gene flow between these populations. The large-scale populations had a significant higher (45.9\%) proportion of individuals assigned to one of the rest populations than the populations at small scale $(22.2 \%$, $F_{1,15}=14.35, P=0.001$ ).

Genetic distances $\left(D_{\mathrm{LR}}\right)$ between populations differed widely, from 0.13 (between HKM3 and HKM4) to 13.61 


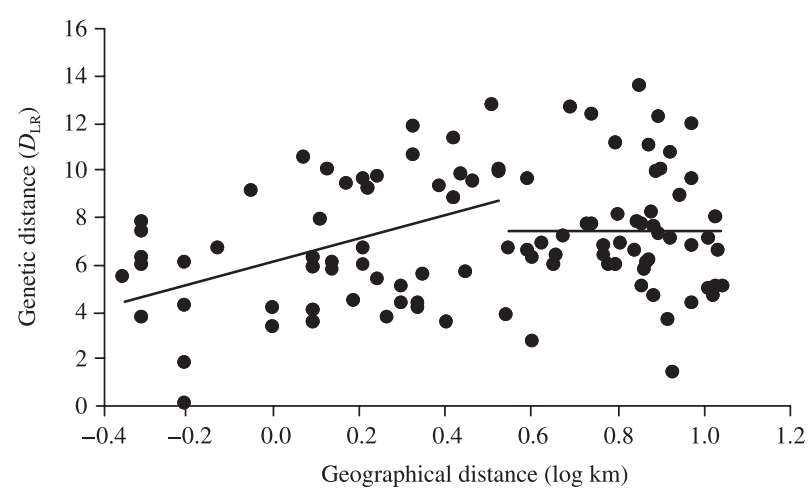

Fig. 3 Correlation of pairwise genetic distances with geographical distances of all populations of Hypochaeris radicata. Genetic distances ( $D_{\mathrm{LR}}$ computed in SPASSIGN) are based on Bayesian assignment values; geographical distances are the shortest distances between the populations $(\log \mathrm{km})$. Correlation coefficients were calculated separately for distances under and over $3.5 \mathrm{~km}$. Correlation coefficients: under $3.5 \mathrm{~km}: r=0.45, R^{2}=0.19, P<0.001$; over $3.5 \mathrm{~km}$ : $r=-0.25, R^{2}=0.06, P=0.48$. Not shown are all samples across all distances: $r=0.24, R^{2}=0.05, P=0.013$ and small-scale samples only: $r=0.32, R^{2}=0.10, P=0.06$.

(between HMA and HSO). The exact test showed that the genetic differentiation of some of the population pairs was significant. According to the Mantel test, the correlation between the pairwise genetic distance and the geographical distance $(\log \mathrm{km})$, using the Bayesian genetic distance value $D_{\mathrm{LR}^{\prime}}$ was not significant for the large-scale study (correlation coefficient $r=-0.05, R^{2}=0.03, P=0.66$ ), but marginally significant for the small-scale study $\left(r=0.32, R^{2}=0.10\right.$, $P=0.06)$, and significant across all samples $\left(r=0.24, R^{2}=\right.$ $0.05, P=0.013)$. This was consistent with the pattern found when using genetic distances determined as $F_{\mathrm{ST}}$ (not shown).

When recalculating isolation by distance for smalland large-scale patterns, based on the entire sample, the explained variance of the small-scale pattern was maximal at a threshold distance of $3.5 \mathrm{~km}\left(r=0.45, R^{2}=0.19\right.$, $P<0.001$ below $3.5 \mathrm{~km}$ and $r=-0.25, R^{2}=0.06 P=0.48$ above $3.5 \mathrm{~km}$, Fig. 3). These results indicate that population differentiation follows an isolation-by-distance pattern up to $3.5 \mathrm{~km}$, with $19 \%$ of the genetic distance explained by geographical distance. Above $3.5 \mathrm{~km}$, the genetic distance does not increase further with geographical distance (Fig. 3).

\section{Discussion}

Habitat fragmentation can alter patterns of gene flow and population structure (Young et al. 1996). Such changes may be site- and species-specific (Jacquemyn et al. 2003) and may depend on plant density (Van Treuren et al. 1994), while these effects may also differ when considering different landscape scales (Hutchison \& Templeton 1999). Hypochaeris radicata is a common species in the highly fragmented and agricultural landscape we studied, and its seeds can disperse over distances of several hundred metres (Soons et al. 2004). When revisiting the small-scale area after 3 years, considerable dynamics of populations was observed, as was expected in this short-lived species. Several newly established sites were found, and as the species does not form a seed bank (Aarssen 1981) this indicates that seeds are dispersing through the landscape.

Our main objective was to investigate the possible effects of habitat fragmentation on genetic structure within and between populations of this species. We hypothesized that part of these effects may be mediated via effects of plant density within populations. Populations with reduced plant density are expected to show reduced levels of genetic diversity due to lower outcrossing rates (Van Treuren et al. 1994) and limited gene flow (Griffin \& Barret 2004), both resulting from lower pollinator attractiveness of low density populations (Karron et al. 1995). However, in contrast to our expectations, we found no difference in genetic diversity between high and low density populations. $F_{\text {IS }}$ values varied between -0.03 (HKE) and 0.14 (HKM), but were not related to plant density. Such differences in $F_{\mathrm{IS}}$ values then might be due to spatial Wahlund effects (Murren 2003 and references therein) as withinpopulation spatial genetic structuring can be high in small populations (Ingvarsson \& Giles 1999).

In all populations high levels of genetic diversity were observed. Similar results have been found in other studies. For example, Hogbin et al. (1998) and Van Rossum et al. (2004) measured the genetic diversity in habitat fragments of the outcrossing species Grevillea barklyana, Primula veris and Primula vulgaris. They found that both verge and nonverge populations, a classification mimicking our high density-low density classification, showed similar high levels of genetic diversity. Godt et al. (1997) suggested that high levels of genetic diversity are common for outcrossing, short-lived species, when levels of between-population gene flow are high. The absence of density effects and the throughout high levels of within-population diversity that we observed in this area may therefore indicate that populations are not isolated here.

This conclusion is corroborated by the between-population studies at the two spatial scales. The weak population differentiation we observed indicates that there were still substantial levels of gene flow. Up to $3.5 \mathrm{~km}$, the gene flow pattern was consistent with isolation by distance, indicating that gene flow was limited by geographical distance and followed a stepping-stone model (Hutchison \& Templeton 1999). Gene flow is expected to take place through both seed and pollen dispersal. Successful seed dispersal must include establishment at new sites, so there must be suitable colonization sites available within a fragmented landscape (Soons \& Heil 2002). The observation of new populations being established in the region we studied between 2001 and 2004 indicates that successful seed 
dispersal did take place at this scale, and was most probably responsible for parts of the isolation-by-distance pattern.

In an earlier study, Soons et al. (2004) modelled seed dispersal and calculated that the majority of the seeds would not disperse beyond $100 \mathrm{~m}$, and only a very small fraction would disperse up to $400 \mathrm{~m}$. In our study, the average distance between the populations within the small-scale area was about $1 \mathrm{~km}$, with the shortest distance between neighbouring populations being $500 \mathrm{~m}$ in the small-scale study. Our results indicate that dispersal, either by pollen or by seeds, occurs over at least a distance of $500 \mathrm{~m}$. This is supported by the results of the assignment test. Of the individuals in the small-scale study, $21.1 \%$ could not be assigned to any population, suggesting they immigrated from outside the study area. Moreover, an additional $22.1 \%$ of the individuals were assigned to non-neighbouring populations. While both pollen and seed dispersal could contribute to these results, the observation of newly established populations at a distance of more than $400 \mathrm{~m}$ strongly suggests that seed dispersal contributed at least partly to the assignment results. This would then indicate that seed dispersal occurs over greater distances than was estimated using aerodynamic models (Soons et al. 2004).

The discrepancy between the modelled dispersal distance and the indirectly measured dispersal distance might be due to the uncertainty in modelling the tail of the dispersal curve (Bullock \& Clark 2000; Cain et al. 2000). Another important parameter in the seed dispersal model of Soons et al. (2004) is the seed release height, as seeds released above the level of the surrounding vegetation can travel longer distances. The majority of the $H$. radicata individuals occurred in linear landscape elements that were open and frequently mown. The seed release height in such habitats may be much higher than in the dense grassland populations that were used to model seed dispersal distances for H. radicata (Soons \& Heil 2002; Soons et al. 2004).

We made an effort to further analyse the overall relationship between geographical and genetic distance. While the overall relationship was significant, our detailed analysis showed that beyond $3.5 \mathrm{~km}$, population differentiation did not follow an isolation-by-distance pattern (Fig. 3). Thus, gene flow exerts its influence up to $3.5 \mathrm{~km}$; above that distance, genetic drift within populations has a larger influence than dispersal between populations (Hutchison \& Templeton 1999). Populations farther apart than $3.5 \mathrm{~km}$ are therefore effectively, genetically isolated from one another.

The use by $H$. radicata of the linear landscape elements as habitats may positively affect gene flow. Recent studies have shown that insects tend to follow these elements rather than crossing monocultured, nonflowering farming areas (Kwak et al. 1998; Dover \& Fry 2001; Tewksbury et al. 2002; Cranmer 2004; Townsend \& Levey 2005). Thus the relatively high threshold distance of $3.5 \mathrm{~km}$ we found may be specific for the present landscape and might be lower in other landscapes lacking the linear elements.

\section{Consequences of habitat fragmentation for $\mathrm{H}$. radicata}

Hypochaeris radicata is characterized as being short-lived, has relatively high population turnover, seed dispersal distances up to several hundred metres, relatively high dispersal (gene flow) rates and no seed bank. These life history features all contribute to the possibility of metapopulation dynamics (Ehrlén \& Eriksson 2003; Ouborg \& Eriksson 2004). The species is present in discrete habitat patches and migration between these patches is common. From the life history and landscape descriptions, and the fact that the migration patterns did not fit any other model (as argued by Freckleton \& Watkinson 2002 and Tero et al. 2003), we conclude that the species persists within the highly fragmented landscape as a true metapopulation (Ouborg \& Eriksson 2004), using linear landscape elements as temporary habitats. The metapopulation dynamics is shown by the relatively large differences found in area covered and location, with local sites where the species had been decimated and other sites that had been colonized when the same region was surveyed 3 years later.

Modelling has suggested that the evolution of dispersal is favoured by succession in a metapopulation context (Olivieri et al. 1995) and as a result of changed ecological conditions during succession (Ronce et al. 2005). Our study shows that such regional dynamics occur for $H$. radicata in the Achterhoek region, which may confirm that the dispersal ability of this species might be subject to evolutionary changes. One of the best examples demonstrating shortterm evolution of dispersal traits is that found in the study by Cody \& Overton (1996), who found evidence for the hypothesis that dispersal traits (in $H$. radicata) might be liable to evolutionary change. However, they did not prove to what extent gene flow really occurs, nor did they prove whether the islands they studied were effectively isolated, or that dispersal has a genetic basis. Our results show that population isolation of $H$. radicata occurs from a distance of $3.5 \mathrm{~km}$ onwards. Results of an ecological study on $H$. radicata (unpublished results) strongly suggest that dispersal traits may have a genetic basis. Both findings confirm the possibility that Cody \& Overton (1996) did indeed observe short-term evolution in $H$. radicata.

In the introduction we argued that $H$. radicata would be sensitive to habitat fragmentation because of its mating system (depending on pollinators), the fact that inbreeding reduces seed set and seed dispersal (Picó et al. 2004; Mix et al. 2006), the calculated maximum dispersal distances of $400 \mathrm{~m}$ (Soons et al. 2004), and the lower plant density of most of the populations. The genetic results, however, suggest that habitat fragmentation has led to a weak population differentiation, with populations maintaining their 
levels of genetic diversity through extensive gene flow by pollen and seeds. Seeds of the species also seem to disperse over considerably greater distances than the 400 m suggested previously. Therefore, we feel justified in claiming that $H$. radicata shows an isolation-by-distance pattern and successfully survives habitat fragmentation as a metapopulation by using suitable but transitory habitat fragments such as linear landscape elements.

\section{Acknowledgements}

Merel Soons kindly provided us with the necessary geographical information. The Dutch National Forest Service kindly permitted us to sample leaf materials in the conservation areas. We are grateful to four anonymous referees for valuable comments. This research was supported by the Netherlands' Organization for Scientific Research (NWO project FLOS, 805-33-451) and by the European Community (TRANSPLANT project, EVK2- 199900042).

\section{Supplementary material}

The supplementary material is available from http://www.blackwellpublishing.com/products/journals/ suppmat/MEC/EC2887/MEC2887sm.htm

Table S1 Pairwise geographical distances ( $\mathrm{km}$, below diagonal) and genetic distances $\left(D_{\mathrm{LR}^{\prime}}\right.$ in bold, above diagonal) between populations of Hypochaeris radicata in the large-scale (upper panel) and small-scale (lower panel) sampling schemes. Most of the population pairs were not significantly differentiated; those that were significantly differentiated are indicated by an asterisk * $(P<0.05)$.

\section{References}

Aarssen LW (1981) The biology of Canadian weeds. 50. Hypochaeris radicata L. Canadian Journal of Plant Science, 61, 365381.

Baudouin L, Piry S, Cornuet JM (2004) Analytical Bayesian approach for assigning individuals to populations. Journal of Heredity, 95, 217-224.

Berry O, Tocher MD, Sarre SD (2004) Can assignment tests measure dispersal? Molecular Ecology, 13, 551-561.

Brown JH, Kodric-Brown A (1977) Turnover rates in insular biogeography: effect of immigration on extinction. Ecology, 58, 445-449.

Bullock JM, Clark RT (2000) Long distance seed dispersal by wind: measuring and modelling the tail of the curve. Oecologia, 124, 506-521.

Byers DL, Waller DM (1999) Do plant populations purge their genetic load? Effects of population size and mating history on inbreeding depression. Annual Review of Ecology and Systematics, 30, 479-513.

Cain ML, Brook GM, Strand AE (2000) Long-distance seed dispersal in plant populations. American Journal of Botany, 87, 12171227.

Cegelski CC, Waits LP, Anderson NJ (2003) Assessing population structure and gene flow in Montana wolverines (Gulo gulo) using assignment-based approaches. Molecular Ecology, 12, 2907-2918.

Cody ML, Overton JMcC (1996) Short-term evolution of reduced dispersal in island plant populations. Journal of Ecology, 84, 5361.

Cranmer L (2004) The use of linear landscape features by pollinators. PhD Thesis. University College Northampton, UK.

Dover JW, Fry GLA (2001) Experimental simulation of some visual and physical components of a hedge and the effects on butterfly behaviour in an agricultural landscape. Entomologia Experimentalis et Applicata, 100, 221-233.

Ehrlén J, Eriksson O (2003) Large-scale spatial dynamics of plants: a response to Freckleton \& Watkinson. Journal of Ecology, 91, 316-320.

Freckleton RP, Watkinson AR (2002) Large-scale spatial dynamics of plants: metapopulations, regional ensembles and patchy populations. Journal of Ecology, 90, 419-434.

Fryxell PA (1957) Mode of reproduction of higher plants. Botanical Review, 23, 135-233.

Godt MJW, Walker J, Hamrick JL (1997) Genetic diversity in the endangered lily Harperocallis flava and a close relative, Tofieldia racemosa. Conservation Biology, 11, 361-366.

Goodell K, Elam DR, Nason JD, Ellstrand NC (1997) Gene flow among small populations of a self-incompatible plant: an interaction between demography and genetics. American Journal of Botany, 84, 1362-1371.

Goudet J (1995) FSTAT (version 1.2): a computer program to calculate F-statistics. Journal of Heredity, 86, 485-486.

Goudet J (2001) FSTAT. A computer program to calculate F-statistics, estimate and test gene diversities and fixation indices. Version 2.9.3. Update from Goudet 1995.

Griffin SR, Barrett SCH (2004) Genetic variation in Trillium erectum (Melanthiaceae), a widespread forest herb in eastern North America. Canadian Journal of Botany, 82, 316-321.

Hartl DL, Clark AG (1989) Principles of Population Genetics. Cambridge University Press, Cambridge, UK.

He T, Krauss SL, Lamont BB, Miller BP, Enright NJ (2004) Longdistance seed dispersal in a metapopulation of Banskia hookeriana inferred from a population allocation analysis of amplified fragment length polymorphism data. Molecular Ecology, 13, 1099-1109.

Hogbin PM, Ayre DJ, Whelan RJ (1998) Genetic diversity and reproductive success of road verge populations of the rare shrub Grevillea barklyana (Proteaceae). Heredity, 80, 180-186.

Hutchison DW, Templeton AR (1999) Correlation of pairwise genetic and geographic distance measures: inferring the relative influence of gene flow and drift on the distribution of genetic variability. Evolution, 53, 1898-1914.

Ingvarsson PK, Giles BE (1999) Kin-structured colonization and small-scale genetic differentiation in Silene dioica. Evolution, 53, 605-611.

Jacquemyn H, Van Rossum F, Brys R et al. (2003) Effects of agricultural land use and fragmentation on genetics, demography and population persistence of the rare Primula vulgaris, and implications for conservation. Belgium Journal of Botany, 136, 5-22.

Kalinowski ST (2004) Counting alleles with rarefaction: private alleles and hierarchical sampling designs. Conservation Genetics, 5, 539-543.

Kalinowski ST (2005) HP-RARE 1.0: a computer program for performing rarefaction on measures of allelic richness. Molecular Ecology Notes, 5, 187-189. 
Karron JD, Thumser NN, Tucker R, Hussenauer AJ (1995) The influence of population density on outcrossing rates in Mimulus ringes. Heredity, 75, 175-180.

Kunin WE (1997) Population size and density effects in pollination: pollinator foraging and plant reproductive success in experimental arrays of Brassica kaber. Journal of Ecology, 85, 225-234.

Kwak MM, Velterop O, Andel J (1998) Pollen and gene flow in fragmented habitats. Applied Vegetation Science, 1, 37-54.

Lande R (1993) Risks of population extinction from demographic and environmental stochasticity and random catastrophes. American Naturalist, 142, 911-928.

Lennartsson T (2002) Extinction thresholds and disrupted plant-pollinator interactions in fragmented plant populations. Ecology, 83, 3060-3072.

Manel S, Berthier P, Luikart G (2002) Detecting wildlife poaching: identifying the origin of individuals with Bayesian assignment tests and multilocus genotypes. Conservation Biology, 16, 650659.

Manel S, Gaggiotti OE, Waples RS (2005) Assignment methods: matching biological questions with appropriate techniques. Trends in Ecology \& Evolution, 20, 136-142.

Manly BJF (1985) The Statistics of Natural Selection. Chapman \& Hall, London.

Mix C, Arens PFP, Ouborg NJ, Smulders MJM (2004) Isolation and characterization of highly polymorphic microsatellite markers in Hypochaeris radicata (Asteraceae). Molecular Ecology Notes, 4, 656-658.

Mix C, Picó FX, Van Groenendael JM, Ouborg NJ (2006) Inbreeding and soil conditions affect dispersal and components of performance of two plant species in fragmented landscapes. Basic and Applied Ecology, 7, 59-69.

Murren CJ (2002) Effects of habitat fragmentation on pollination: pollinators, pollinia viability and reproductive success. Journal of Ecology, 90, 100-107.

Nei M (1973) Analysis of gene diversity in subdivided populations. Proceedings of the National Academy of Sciences, USA, 70, 3321-3323.

Olivieri I, Michalakis Y, Gouyon PH (1995) Metapopulation genetics and the evolution of dispersal. American Naturalist, 146, 202-228.

Ouborg NJ, Eriksson O (2004) Towards a metapopulation concept for plants. In: Metapopulation Ecology, Genetics and Evolution (eds Hanski I, Gaggiotti O), pp. 447-469. Academic Press, San Diego, California.

Ouborg NJ, Piquot Y, van Groenendael JM (1999) Population genetics, molecular markers and the study of dispersal in plants. Journal of Ecology, 87, 551-568.

Pálsson S (2004) Isolation by distance, based on microsatellite data, tested with spatial autocorrelation (SPAIDA) and assignment test (sPAssign). Molecular Ecology Notes, 4, 143-145.

Picó FX, Ouborg NJ, van Groenendael JM (2004) Influence of selfing and maternal effects on life-cycle traits and dispersal ability in the herb Hypochaeris radicata (Asteraceae). Botanical Journal of the Linnean Society, 146, 163-170.

Rannala B, Mountain L (1997) Detecting immigration by using multilocus genotypes. Proceedings of the National Academy of Sciences, USA, 94, 9197-9221.

Raymond M, Rousset F (1995) GENEPOP (version 1.2): population genetics software for exact tests and ecumenicism. Journal of Heredity, 86, 248-249.
Rice WR (1989) Analyzing tables of statistical tests. Evolution, 43, 223-225.

Ronce O, Brachet S, Olivieri I, Gouyon PH, Clobert J (2005) Plastic changes in seed dispersal along ecological succession: theoretical predictions from an evolutionary model. Journal of Ecology, 93, 431-440.

Schaffer ML (1987) Minimum viable populations: coping with uncertainty. In: Viable Populations for Conservation (ed. Soulé ME), pp. 69-86. Cambridge University Press, Cambridge, UK.

Schemske DS, Husband BC, Ruckelshaus MH et al. (1994) Evaluating approaches to the conservation of rare and endangered plants. Ecology, 75, 584-606.

Soons MB, Heil GW (2002) Reduced colonization capacity in fragmented populations of wind-dispersed grassland forbs. Journal of Ecology, 90, 1033-1043.

Soons MB, Heil GW, Nathan R, Katul GG (2004) Determinants of long-distance seed dispersal by wind in grasslands. Ecology, 85, 3056-3068.

Tackenberg O (2003) Modelling long-distance dispersal of plant diaspores by wind. Ecological Monographs, 73, 173-189.

Tero N, Aspi J, Siikamäki P, Jäkäläniemi A, Toumi J (2003) Genetic structure and gene flow in a metapopulation of an endangered plant species, Silene tatarica. Molecular Ecology, 12, 2073-2085.

Tewksbury JJ, Levey DJ, Haddad NM et al. (2002) Corridors affect plants, animals, and their interactions in fragmented landscapes. Proceedings of the National Academy of Sciences, USA, 99, 1292312926.

Townsend PA, Levey DJ (2005) An experimental test of whether habitat corridors affect pollen transfer. Ecology, 86, 466-475.

Van Rossum F, Campos de Sousa S, Triest L (2004) Genetic consequences of habitat fragmentation in an agricultural landscape on the common Primula veris, and comparison with its rare congener, P. vulgaris. Conservation Genetics, 5, 231-245.

Van Treuren R, Bijlsma R, Ouborg NJ, Kwak MM (1994) Relationships between plant density, outcrossing rates and seed set in natural and experimental populations of Scabiosa columbaria. Journal of Evolutionary Biology, 7, 287-302.

Weir BS, Cockerham CC (1984) Estimating F-statistics for the analysis of population structure. Evolution, 38, 1358-1370.

Whitlock MC, McCauley DE (1999) Indirect measures of gene flow and migration: $F_{\mathrm{ST}} \neq 1 /(4 N m+1)$. Heredity, 82, 117-125.

Young A, Boyle T, Brown T (1996) The population genetic consequences of habitat fragmentation for plants. Trends in Ecology \& Evolution, 11, 413-418.

This study is part of Carolin Mix's PhD thesis on the genetic effects of habitat fragmentation on plant populations. Jan van Groenendael is head of the Department of Ecology and interested in population dynamics and population genetics of plant species and the conservation of biodiversity in fragmented landscapes. Joop Ouborg, as an Assistant Professor, is interested in molecular ecology of plants and animals and eco-dynamics of life-history traits. Ramses Rengelink is a research assistant. René Smulders and Paul Arens are (senior) researchers and share a common interest in studies on genetic diversity, population genetics and conservation biology issues. 